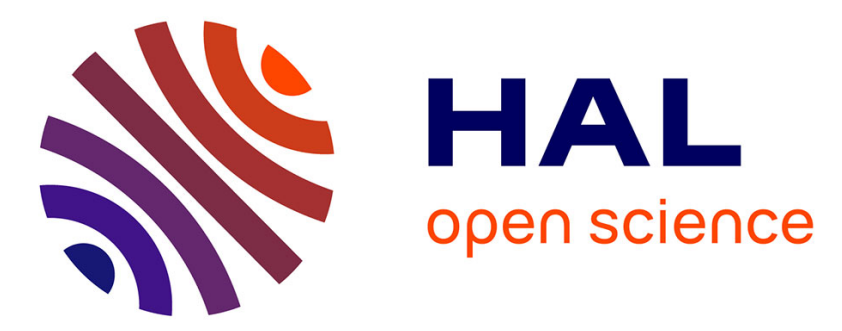

\title{
Anthropophilic mosquitoes and malaria transmission in the eastern foothills of the central highlands of Madagascar
}

\author{
Lala Andrianaivolambo, Olivier Domarle, Milijaona Randrianarivelojosia, \\ Jocelyn Ratovonjato, Gilbert Le Goff, Arthur Talman, Frédéric Ariey, Vincent \\ Robert
}

\section{To cite this version:}

Lala Andrianaivolambo, Olivier Domarle, Milijaona Randrianarivelojosia, Jocelyn Ratovonjato, Gilbert Le Goff, et al.. Anthropophilic mosquitoes and malaria transmission in the eastern foothills of the central highlands of Madagascar. Acta Tropica, 2010, 116 (3), pp.240-245. 10.1016/j.actatropica.2010.08.017 . hal-03359121

\section{HAL Id: hal-03359121 \\ https://hal.science/hal-03359121}

Submitted on 30 Sep 2021

HAL is a multi-disciplinary open access archive for the deposit and dissemination of scientific research documents, whether they are published or not. The documents may come from teaching and research institutions in France or abroad, or from public or private research centers.
L'archive ouverte pluridisciplinaire HAL, est destinée au dépôt et à la diffusion de documents scientifiques de niveau recherche, publiés ou non, émanant des établissements d'enseignement et de recherche français ou étrangers, des laboratoires publics ou privés.

\section{(ㅇ)(1) $\$$}

Distributed under a Creative Commons Attribution - NonCommercial - NoDerivatives $\mid 4.0$ 


\title{
Anthropophilic mosquitoes and malaria transmission in the eastern foothills of the central highlands of Madagascar
}

\author{
Lala Andrianaivolambo ${ }^{\mathrm{a}}$, Olivier Domarle ${ }^{\mathrm{a}}$, Milijaona Randrianarivelojosia ${ }^{\mathrm{a}}$, Jocelyn Ratovonjato ${ }^{\mathrm{a}}$, \\ Gilbert Le Goff $^{\mathrm{a}, \mathrm{b}}$, Arthur Talman ${ }^{\mathrm{a}}$, Frédéric Ariey ${ }^{\mathrm{a}, \mathrm{c}}$, Vincent Robert ${ }^{\mathrm{a}, \mathrm{b}, *}$ \\ ${ }^{a}$ Groupe de Recherche sur le Paludisme, Institut Pasteur de Madagascar, Antananarivo, \\ Madagascar \\ ${ }^{\mathrm{b}}$ Unité de recherche 16, Institut de Recherche pour le Développement, Montpellier, France \\ ${ }^{\mathrm{c}}$ Institut Pasteur du Cambodge, Phnom Penh, Cambodge \\ *Corresponding author: \\ Vincent ROBERT \\ UR-016, Institut de Recherche pour le Développement (IRD) \\ 911 avenue agropolis, BP 64501 \\ 34394 Montpellier Cedex 5, France \\ Tel : +33467416127 \\ vincent.robert@ird.fr
}

\begin{abstract}
Malaria remains a major public health problem in Madagascar, as it is the first cause of morbidity in health care facilities. Its transmission remains poorly documented. An entomological study was carried out over one year (October 2003 to September 2004) in Saharevo, a village located at an altitude of $900 \mathrm{~m}$ on the eastern edge of the Malagasy central highlands. Mosquitoes were sampled weekly upon landing on human volunteers and in various resting-places. Out of 5,515 mosquitoes collected on humans, 3,219 (58.4\%) were anophelines. Eleven anopheline species were represented, among which Anopheles funestus, An. gambiae, An. arabiensis and An. mascarensis. Out of 677 mosquitoes collected in bedrooms by pyrethrum spray catches and in MuirheadThomson pits, 656 (96.9\%) were anopheline belonging to these four latter species. The proportion of mosquitoes that fed on human varied according to the resting places and the mosquito species: $86 \%$ of An. funestus resting in bedrooms fed on humans, whereas only $16 \%$ of An. funestus and $0 \%$ of An. mascarensis resting in pits fed on humans. The proportion of anopheline mosquitoes infected with human Plasmodium was measured by circumsporozoite protein-ELISA: 10/633 An. funestus (1.58\%), 1/211 An. gambiae s.l. (0.48\%) and 2/268 An. mascarensis $(0.75 \%)$. The annual entomological inoculation rate (number of bites of infected anophelines per adult) was estimated at 2.78. The transmission was mainly due to An. funestus and only observed in the second half of the rainy season, from February to May. These results are discussed in the context of the current malaria vector control policy in Madagascar.
\end{abstract}

Keywords: malaria; Plasmodium falciparum; Plasmodium vivax; Anopheles funestus; Anopheles gambiae; Anopheles arabiensis; Anopheles mascarensis; transmission; highlands; Madagascar. 


\section{Introduction}

Malaria remains the most prevalent health problem in Madagascar, as it is the first source of morbidity in health care facilities. The four plasmodial species infecting human, Plasmodium falciparum, $P$. vivax, $P$. malariae and $P$. ovale, occur in Madagascar. The intensity of plasmodial transmission varies according to the geographical areas of the island (Mouchet et al., 2004). The eastern and western coastal regions are characterised by hyperendemic malaria with a transmission season of more than six months per year. In the central highlands, the sporogonic development of the parasite in the mosquito vector is strongly influenced by temperature, which varies according to altitude. Malaria is considered stable up to an altitude of $1,000 \mathrm{~m}$, unstable with seasonal transmission from November to May between 1,000 and 1,500 m, and rare or absent over 1,500 m. In the highlands, the main vector is Anopheles funestus, with lower endophily and anthropophily than in mainland Africa (Grejbine, 1966; Fontenille et al., 1990; Laventure et al., 1996; Rajaonarivelo et al., 2004; Robert et al., 2006). Altitudes superior to $900 \mathrm{~m}$ are clearly a limiting factor for the distribution of An. gambiae (Léong Pock Tsy et al., 2003) but, when present at moderate densities, it is a secondary vector. An. arabiensis and An. mascarensis, although mostly zoophylic, are also secondary vectors (Le Goff et al., 2003).

The national malaria control campaigns carried out in the 1950s and 1960s were successful and led to the disappearance of An. funestus from the central highlands (Fontenille and Rakotoarivony, 1988; Randrianarivelojosia et al., 2008). When antivectorial measures stopped, An. funestus recolonised the central highlands progressively, and from 1985 to 1990 the Madagascar highlands suffered an epidemic of falciparum malaria, which caused the deaths of 40,000 inhabitants (Mouchet et al., 2004).

House spraying with DDT was annually performed by the Ministry of Health in the central highlands, between altitudes of 1,000 and 1,500 m, from 1993 to 1998 (Romi et al., 2002). From 1999 to 2005 these general campaigns were replaced by more selective operations in restricted areas of the western part of the highlands. Pyrethroid insecticides have replaced DDT since 2005.

This entomological study was carried out to document the anthropophilic mosquitoes and to estimate the malaria transmission in a village typical of the eastern foothill area of the Malagasy highlands during 12 consecutive months. In this village, the entomological transmission, although moderate, is a reality. Inhabitants who would not take any protection against mosquito bites receive, in average, 2.78 bites of infected anophelines between February and May.

\section{Materials and methods}

Study site

The Malagasy central highlands represent about $20 \%$ of the total area of Madagascar. They are characterised by altitudes exceeding $800 \mathrm{~m}$ above sea level. High human densities are observed in the provinces of Antananarivo and Fianarantsoa. The climate is tropical with two contrasting seasons. The dry season ordinary extends over six months, typically from May to October, with relatively low temperatures $\left(<15^{\circ} \mathrm{C}\right)$. The rainy season lasts from November to April, with maximum rainfall in February (Jeanne et al., 2002).

The village of Saharevo $\left(18^{\circ} 82^{\prime} \mathrm{S}, 48^{\circ} 10^{\prime} \mathrm{E}, 900 \mathrm{~m}\right)$ is located in the Moramanga district, Alaotra-Mangoro region, former province of Toamasina, Madagascar. It is situated $50 \mathrm{~km}$ east of Antananarivo ( $85 \mathrm{~km}$ by road), $3 \mathrm{~km}$ from the eastern bank of the Mangoro River, and $4 \mathrm{~km}$ north of the national road linking Antananarivo and Toamasina. The study area is exposed to dominant easterly humid winds from the Indian Ocean, which enhance the wet season duration and weaken the impact of the dry season. The mean annual rainfall is $1,400 \mathrm{~mm}$, ranging monthly between 255 and $3 \mathrm{~mm}$, in December and September, respectively. The average temperatures of the hottest and coldest months are $23^{\circ}$ and $16^{\circ} \mathrm{C}$ in February and August, respectively (Figure 1).

The population of Saharevo (approximately 250 inhabitants) is mainly devoted to agricultural activities with an accessory production of charcoal. Rice fields are occasionally present (Rakotomanana et al., 2006); one round of rice production occurs, from January-February to AprilMay. There is no school for children in the village. The habitat is composed of 51 houses that are 
made of bricks or cob with roofs, which are covered with thatch ( $90 \%$ of houses), tiles or sheet metal; all houses but one have only one level. A primary health care centre has been built in this village. No vector control measures have been performed at community level such as insecticide spraying during the study period or during the previous decade. Inhabitants do not use any special measures to protect themselves from mosquito bites. None of them used bed nets during the study period. In October 2005 (i.e. after the study period), as part of the national malaria control policy, the district health authorities of Moramanga provided families having children under five years old or pregnant women with 48 insecticide treated bed nets for free (Randrianasolo, personal communication).

The village has zebu cattle (about 20 individuals) that spend the night in four enclosures spread throughout the village or at its nearby periphery. Other domestic animals, such as dogs, cats and poultry are also found in the village; but pigs are taboo in this village.

\section{Entomological study}

Collecting mosquitoes. The study was carried out from October 6, 2003 to September 27, 2004, as part of the entomological monitoring of the Malagasy National Malaria Control Programme. It was conducted each week from November 2003 to June 2004, and every other week in October 2003 and from July 2004 to September 2004; observations were made 42 weeks in total. Two sampling methods were used to assess on the one hand mosquitoes aggressive towards man and on the other hand resting mosquitoes. The first method involved all night human landing catches with volunteers staying indoors or outdoors (WHO, 1992). Female mosquitoes, aggressive towards human subjects, were collected as they landed on the bare legs of volunteers who acted simultaneously as bait and trappers. Eight pairs of volunteers worked simultaneously throughout the night from 7 p.m. to 5 a.m. in four houses and in four outdoor sites within the village. The total number of human-nights was 672 for the whole study, equally distributed among indoor and outdoor collections (336 each). The second method involved the collection of resting mosquitoes. Endophilic resting mosquitoes were collected in the morning from a mean of 3.3 bedrooms using pyrethroid spray catches. The total of bedroom-nights was 140 for the whole study. Exophilic resting mosquitoes were collected in a mean of 4.2 Muirhead-Thomson' pit shelters examined early after sunrise (Muirhead-Thomson, 1958). The total number of pit-nights was 176 for the whole study. Diagnosis of anopheline mosquitoes was performed using the determination keys of Gillies and Coetzee (1987) and Grjebine (1966). Approval to conduct research on malaria involving human subjects in Saharevo has been delivered by the Ministère de la Santé et du Planing Familial de Madagascar (Authorisation 013/04SANPF/CAB).

PCR determination. Because previous studies have shown the study area as a zone of sympatry between An. gambiae and An. arabiensis (Léong Pock Tsy et al., 2003; Le Goff et al., 2006) mosquitoes from the An. gambiae complex were determined using PCR (Scott et al., 1993). Blood meal analysis. Since the four species An. funestus, An. gambiae, An. arabiensis and An. mascarensis are the only known mosquitoes to be potential vectors of malaria in this area, these species were examined for anthropophily and infectivity. Anthropophily was estimated using blood fed resting mosquitoes. Abdomens were squashed on filter paper, then dried and conserved at $4^{\circ} \mathrm{C}$ with silica gel. Blood spots were tested with an ELISA (Enzyme-Linked Immunosorbent Assay) with several antibodies specific for human, bovid, swine and dog (Beier et al., 1988b).

CSP ELISA. Infectivity was estimated using the head and thorax kept individually in waterproof vials containing silica gel, and placed at $-20^{\circ} \mathrm{C}$. The head and thorax were tested (Robert et al., 1988c) by an ELISA-CSP (Circumsporozoite Protein) to detect the presence of a plasmodial infection and, in a second step, the plasmodial species $P$. falciparum, $P$. malariae, or $P$. vivax (Beier et al., 1988a; Wirtz et al., 1987).

Entomological and parasitological indexes. Sporozoitic indexes were estimated using all the anophelines tested by ELISA, without distinction in collection methods. The daily biting rate was calculated as the ratio of the number of mosquitoes caught landing on human subjects to the number of human-nights. The endophagic rate was estimated from mosquitoes sampled by human landing 
collection (indoors / (indoors + outdoors)). Anthropophily and percentage of zebu blood fed mosquitoes were estimated from samples of resting mosquitoes. Since dwellers spend all nights in their houses, the entomological inoculation rate was calculated from the product of the indoor human biting rates and the sporozoitic indexes.

\section{Results}

With human landing catches, 5,515 mosquitoes were collected. Anophelines were the most abundant mosquitoes with 3,219 (58.4\%) as against 2,171 Culex (39.4\%), 40 Aedes (0.7\%), 80 Mansonia (1.4\%) and 5 Coquilletidia (0.1\%) (Table 1). Four anopheline species, An. funestus, An. gambiae, An. arabiensis and An. mascarensis were potential malaria vectors with a total 1,194 mosquitoes by human landing catches and 656 with collection of resting mosquitoes $(21.7 \%$ and $96.9 \%$ of the collections of aggressive and resting mosquitoes, respectively).

Anopheles funestus. There was a monthly variation in indoor and outdoor catches on human subjects, with an inordinate maximum in April. Collections of resting mosquitoes showed the same pattern of monthly variation. Total number collected outdoors was 2.1 times higher (295/140) than indoors (Table 2). Hourly variation of aggressiveness showed a maximum indoors and outdoors at 2-3 a.m. but with higher relative aggressiveness indoors before 1 a.m. and conversely higher relative aggressiveness outdoors after $1 \mathrm{a} . \mathrm{m}$. (Figure 2). The mean biting rate estimated by indoor collections was 0.372 bites per man per night (Table 2). The proportions of bloodmeal taken from human subjects (i.e. anthropophily) were $90 \%$ and $21 \%$ for mosquitoes resting in bedrooms and pits, respectively. This is in accordance with zoophily for zebus (13\% and $74 \%$ respectively). Few bloodmeals were taken from human+bovids (6/140), few from dogs (3/140) and none from swines. The endophagic rate for biting activity was $32.2 \%$ (Table 3). Ten An. funestus were ELISA-CSP positive from February 11 to May 11, among which 3 aggressive towards man indoors, 4 aggressive towards man outdoors and 3 resting in bedrooms. The mean sporozoitic index was $10 / 633=1.58 \%$, with nine positive for $P$. falciparum and two $P$. vivax (one was positive for these two plasmodial species). The annual entomological inoculation rate was estimated to $2.15(0.372 \times 1.58 \% \times 365$ days) bites of infected An. funestus per adult.

Anopheles gambiae and An. arabiensis. Of 316 mosquitoes from the An. gambiae complex collected by any methods during the whole study, 238 (75\%) were analysed to identify cryptic species and were unambiguously assigned to An. gambiae and An. arabiensis with various relative proportion according to sampling method. With human landing collections (indoors and outdoors) and pyrethrum spray catches, the relative percentage of An. gambiae s.s. among the whole An. gambiae s.l. was $68 \%$, with non significant variation between these 3 samples, in contrast with $16 \%$ in exophilic mosquitoes collected in pits ( $\mathrm{p}<10^{-5}$ by chi square test). Monthly maximal aggressiveness was observed in March for An. gambiae and An. arabiensis. Hourly maximal aggressiveness was observed at 1-2 a.m. for An. gambiae s.l., indoors and outdoors. The mean biting rate estimated by indoor collections was 0.104 bites per man per night for An. gambiae s.l. $(0.070+0.034$; Table 2$)$. The proportions of bloodmeal taken from human subjects (i.e. anthropophily) were $0 \%$ for An. gambiae s.l. resting in pits, which is in accordance with $100 \%$ zoophily for zebus (percentages obtained from 4 An. gambiae and 24 An. arabiensis). No bloodmeals were taken from dogs or swines. One An. gambiae s.l. aggressive towards man outdoors on March 23 was ELISA-CSP positive for P. falciparum; unfortunately, this mosquito was not determined at species level. The mean sporozoitic index was $1 / 211(0.48 \%)$. The annual entomological inoculation rate was estimated to $0.18(0.104 \times 0.48 \% \times 365$ days $)$ bites of infected An. gambiae s.l. per adult.

Anopheles mascarensis. This was the most abundant potential malaria vector. Monthly maximal aggressiveness was observed in April. Hourly maximal aggressiveness was observed between midnight and 1 a.m., both indoors and outdoors. The mean biting rate estimated by indoor 
collections was 0.165 bites per man per night (Table 2). The proportions of bloodmeal taken from human subjects (i.e. anthropophily) were $0 \%$ for An. mascarensis resting in pits, which is in line with the $97 \%$ zoophily for zebus. Four bloodmeals (3\%) were taken from dogs. Two An. mascarensis collected on March 23 and May 17 were ELISA-CSP positive for P. malariae and $P$. falciparum, respectively; the former was resting in a pit shelter and the latter was collected aggressive towards man outdoors. The mean sporozoitic index was $2 / 268=0.75 \%$. The annual entomological inoculation rate was estimated to 0.45 ( $0.165 \times 0.75 \% \times 365$ days) bites of infected An. mascarensis per adult person.

Thus, the malaria transmission measured as the total annual entomological inoculation rate (total of the entomological inoculation rates from the four species, An. funestus, An. gambiae, An. arabiensis and An. mascarensis) was 2.78 bites of infected anophelines per adult. It was based on malariainfected mosquitoes sampled during four months, from February to May.

\section{Discussion}

In the studied village of Saharevo, An. funestus was the major vector of malaria, with nearly $75 \%$ of the total infected mosquitoes observed. The three other anopheline species, An. gambiae, An. arabiensis and An. mascarensis act as secondary vectors. Similar observations were made in Malagasy highlands since the 1960s (Grejbine, 1966; Léong Pock Tsy et al., 2003; Le Goff et al., 2003; Robert et al., 2006). The transmission season starts in February in the middle of the rainy/hot season and lasts until May at the beginning of the dry season. The successive peaks of vector density, An. gambiae and An. arabiensis in March and An. funestus in April, suggests a shift in the transmission from An. gambiae s.l. to An. funestus, as classically observed in savannah areas of continental Africa (Gillies \& Coetzee, 1987; Robert et al., 1988b). The level of malaria transmission in Saharevo estimated at 2.78 bites of infected anophelines per man per year is consistent with other studies performed in the Malagasy central highlands: 2.49 in Analamiranga at $900 \mathrm{~m}$ (Robert et al., 2006), 6.06 in Ambohimena at $940 \mathrm{~m}$ (Rajaonarivelo et al., 2004) and 0.91 in Manarintsoa at $1250 \mathrm{~m}$ (Fontenille et al., 1990). However in the western foothill area of the Malagasy highlands, the sporozoitic indexes are lower than on the eastern edge, suggesting a better survival of vectors in Saharevo, in agreement with its location in a wetter area.

Rice fields are known to be important breeding sites of many mosquito species, especially those that are malaria vectors in continental Africa and in Madagascar (Robert et al., 1988a, 2002; Laventure et al., 1996). In our study site, only one round of rice production occurs, which differed from most villages of the western boarder of Malagasy central highlands where two rounds typically take place, increasing the period of malaria transmission (Rajaonarivelo et al., 2004; Robert et al., 2006).

An. funestus, An. gambiae and An. arabiensis demonstrated a moderate tendency to exophily both for biting and resting behaviour, and zoophily for bloodmeals. Individual mosquitoes that enter in a house usually bite human beings and rest indoors for the subsequent bloodmeal digestion and egg development. In contrast, those that do not enter in a house, mainly bite zebus, and rest outdoors. Consequently, once may question the purposefulness of calculating anthropophily based on mosquitoes sampled in bedrooms and pit-shelters as a whole. Populations sampled with the two methods would have to be subjected to different weights in the calculation. This cannot, however be achieved without first knowing the relative population size of resting anophelines in bedrooms and pit-shelters. The zoophilic behaviours of An. funestus and An. gambiae are a remarkable feature, not yet fully understood in Madagascar (Duchemin et al., 2001); by contrast, in the whole of continental Africa, these species appear fully anthropophilic. An. mascarensis exhibits a marked exophily, both for biting and resting activities. It is of interest to note the relatively low ratio of zebus/men (about $20 / 250=8 \%$ ) along side the high zoophily (zebus), pinpointing the high attractiveness of bovid for anophelines in this village, like in other villages of the Malagasy central highlands (Rajaonarivelo et al., 2004; Robert et al., 2006). However, the characters linking endophily and exophily are not absolute; for instance, one infected An. mascarensis was collected in outside shelter, demonstrating 
endo-exophilic behaviour.

The $P$. falciparum prevalence is known in the general (asymptomatic) population of inhabitants: among the 2-9 year old, during our entomological study, it ranges from $35.6 \%$ in May 2004 to $1.3 \%$ in September 2004, with a monthly average of $12.9 \%$ (Domarle and colleagues, unpublished results). Among the 9,556 outpatients (inhabitants of Saharevo and the surrounding hamlets) seen at the primary health centre at Saharevo from 1996 to 2005 (102 months), 13.3\% harboured Plasmodium in their blood smears and were diagnosed with a malaria attack with P. falciparum (97.6\%), P. vivax (1.9\%), P. malariae $(0.6 \%)$ and P. ovale $(0.2 \%)$ (the total exceeds by little $100 \%$ due to 4 mixed infections). In this village, a 60 -year-old adult experienced an average of 32 malaria attacks, with a maximum of 2.6 malaria attacks per annum between 2 and 4 years of age (Rabarijoana et al., 2009). These observations rank malaria as one of the first causes for medical attention seeking in the village. Such association between low-level transmission and high malaria burden have been found previously (Robert et al., 2006). This demonstrates that no level of malaria transmission is acceptable in terms of public health.

In conclusion, our study provides further data from a typical village in the eastern foothill area of the Madagascar highlands, which highlights the huge parasitological consequences of relatively low entomological transmission. These results advocate for anopheline vector control measures, which along side antimalarial drugs, positively impact on malaria burden in Malagasy foothill areas (Mouchet et al., 2004). They may help to adapt the upcoming vector control measures mainly based on indoor spraying of insecticide in the Malagasy highlands, especially where one single round of rice production occurs, and insecticide treated bed nets through the whole country.

\section{Acknowledgements}

We are grateful to the inhabitants of Saharevo for their cooperation throughout this study, to the members of the technical staff of Unité d'Entomologie médicale, Institut Pasteur de Madagascar for their assistance. This study was supported by the Institut Pasteur de Madagascar and by the Institut de Recherche pour le Développement.

\section{References}

Beier, M.S., Schwartz, I.K., Beier, J.C., Perkins, P.V., Onyango, F., Koros, J.K., Campbell, G.H., Andrysiak, P.M., Brandling-Bennett, A.D., 1988a. Identification of malaria species by ELISA in sporozoite and oocyst infected Anopheles from western Kenya. Am. J. Trop. Med. Hyg. 39, 323327.

Beier, J.C., Perkins, P.V., Wirtz, R.A., Koros, J., Diggs, D., Gargan, T.P. 2nd, Koech, D.K., 1988 b. Bloodmeal identification by direct enzyme-linked immunosorbent assay (Elisa), tested on Anopheles (Diptera : Culicidae) in Kenya. J. Med. Entomol. 25, 9-16.

Duchemin, J.B., Léong Pock Tsy, J.M., Rabarison, P., Roux, J., Coluzzi, M., Costantini, C., 2001. Zoophily of Anopheles arabiensis and An. gambiae in Madagascar demonstrated by odour-baited entry traps. Med. Vet. Entomol. 15, 50-57.

Fontenille, D., Lepers, J.P., Campbell, G.H., Coluzzi, M., Rakotoarivony, I., Coulanges, P., 1990. Malaria transmission and vector biology in Manarintsoa, high plateaux of Madagascar. Am. J. Trop. Med. Hyg. 43, 107-115.

Fontenille, D., Rakotoarivony, I., 1988. Reappearance of Anopheles funestus as a malaria vector in Antananarivo region, Madagascar. Trans. R. Soc. Trop. Med. Hyg. 82, 644-645.

Gillies, M.T., Coetzee, M., 1987. A supplement to the Anophelinae of Africa South of the Sahara. Publication of the South African Institute for Medical Research, N55, 143p.

Grejbine, A, 1966. Insectes Diptères Culicidae Anophelinae. Faune de Madagascar. ORSTOM CNRS Ed. Tome 22, Paris 487 p. 
Jeanne, I., Randremanana, R., Robert, V., Ariey, F., Tombo, M.L., Wilmé, L., Ranivoarisoa, S., Duchemin, J.B., 2002. Biogeography of Madagascar. Madagascar Malaria Map. Institut Pasteur de Madagascar, Antananarivo, pp. 3-9.

Laventure, S., Mouchet, J., Blanchy, S., Marrama, L., Rabarison, P., Andrianaivolambo, L., Rajaonarivelo, E., Rakotoarivony, I., Roux, J., 1996. Le riz: source de vie et de mort sur les plateaux de Madagascar. Cahiers Santé 6, 79-86.

Le Goff, G., Léong Pock Tsy, J.M., Robert V., 2006. Molecular characterization of the malaria vector Anopheles gambiae s.s. in Madagascar. Med. Vet. Entomol. 20, 259-260.

Le Goff, G., Randimby, F.M., Rajaonarivelo, V., Laganier, R., Léong Pock Tsy, J.M., Ceianu, C.S., Duchemin, J.B., Robert, V., 2003. Anopheles mascarensis de Meillon 1947, vecteur de paludisme dans le Moyen-Ouest de Madagascar? Arch. Inst. Pasteur Madagascar 69, 57-62.

Léong Pock Tsy, J.M., Duchemin, J.B., Marrama, L., Rabarison, P., Le Goff, G., Rajaonarivelo, V., Robert, V., 2003. Distribution of the species of the Anopheles gambiae complex, and first evidence of Anopheles merus as a malaria vector in Madagascar. Malaria J. 2: 33.

Mouchet, J., Carnevale, P., Coosemans, M., Julvez, J., Manguin, S., Richard-Lenoble, D., Sircoulon, J., 2004. Biodiversité du paludisme dans le monde. John Libbey Eurotext, Paris, $428 \mathrm{p}$.

Muirhead-Thomson R.C., 1958. A pit shelter for sampling outdoor mosquito population. Bull. World Health Organ. 19, 241-261.

Rabarijaona, L.P., Randrianarivelojosia, M., Raharimalala, L.A., Ratsimbasoa, A., Randriamanantena, A., Randrianasolo, L., Ranarivelo, L.A., Rakotomanana, F., Randremanana, R., Ratovonjato, J., Rason M.A., Duchemin, J.B., Tall, A., Robert, V., Jambou, R., Ariey, F., Domarle, O., 2009. Longitudinal survey of malaria morbidity over 10 years in Saharevo (Madagascar): further lessons for strengthening malaria control. Malar J. 8: 190.

Rajaonarivelo, V., Le Goff, G., Cot, M., Brutus, L., 2004. Les anophèles et la transmission du paludisme à Ambohimena, village de la marge occidentale des Hautes-Terres malgaches. Parasite 11, 75-82.

Rakotomanana, F., Rakotoniaina, S., Randremanana R.V., Rasolomamonjy, J.A., Bénié, G.B., Rakotondraompiana S.A., 2006. Amélioration de la classification d'image par la méthode contextuelle ICM: application à la télédétection des gîtes larvaires potentials du paludisme à Madagascar. Télédétection 6, 19-29.

Randrianarivelojosia, M., Raveloson, A., Randriamanantena, A., Juliano, J.J., Andrianjafy, T., Raharimalala, L.A., Robert, V., 2009. Lessons learnt from the six decades of chloroquine use (1945-2005) to control malaria in Madagascar. Trans. R. Soc. Trop. Med. Hyg. 103, 3-10.

Robert, V., Le Goff, G., Andrianaivolambo, L., Randimby, F.M., Domarle, O., Randrianarivelojosia, M., Raharimanga, V., Raveloson, A., Ravaonjanahary, C., Ariey, F., 2006. Moderate transmission but high prevalence of malaria in Madagascar. Int. J. Parasitol. 36, 12731281.

Robert, V., Le Goff, G., Ariey, F., Duchemin, J.B., 2002. A possible alternative method for collecting mosquito larvae in rice fields. Malar. J. 2002, 1: 4.

Robert, V., Ouari, B., Ouedraogo, V., Carnevale, P., 1988a. Etude écologique des Culicidae adultes et larvaires dans la rizière de la Vallée du Kou, Burkino Faso. Acta Tropica 45, 351-359.

Robert, V., Carnevale, P., Ouedraogo, V., Petrarca, V., Coluzzi, M., 1988b. La transmission du paludisme humain dans un village de savane du sud-ouest du Burkina Faso. Ann. Soc. Belge Méd. Trop. $68: 107-121$.

Robert, V., Verhave, J.P., Ponnudurai, T., Louwé, L., Scholtens, P., Carnevale, P., 1988c. Study of the distribution of circumsporozoite antigen in Anopheles gambiae infected with Plasmodium falciparum, using the enzyme-linked immunosorbent assay. Trans. R. Soc. Trop. Med. Hyg. 82, 389-91.

Romi, R., Razaiarimanga, M.C., Raharimanga R. Rakotondraibe E.M., Ranaivo L.H., Pietra V., Raveloson A., Majori G., 2002. Impact of the malaria control campaign (1993-1998) in the 
highlands of Madagascar: parasitological and entomological data. Am. J. Trop. Med. Hyg. 66, 26.

Scott, J.A., Brogdon, W.G., Collins, F.H., 1993. Identification of single specimens of the Anopheles gambiae complex by the polymerase chain reaction. Am. J. Trop. Med. Hyg. 49, 520-529.

WHO, 1992. Entomological field techniques for malaria control. World Health Organisation, Geneva.

Wirtz, R.A., Zavala, F., Charoenvit, Y., Campbell, G.H., Burkot, T.R., Schneider, I., Esser, K.M., Beaudoin, R.L., Andre, R.G., 1987. Comparative testing of monoclonal antibodies against Plasmodium falciparum sporozoites for ELISA development. Bull. World Health Organ. 65, 3945. 


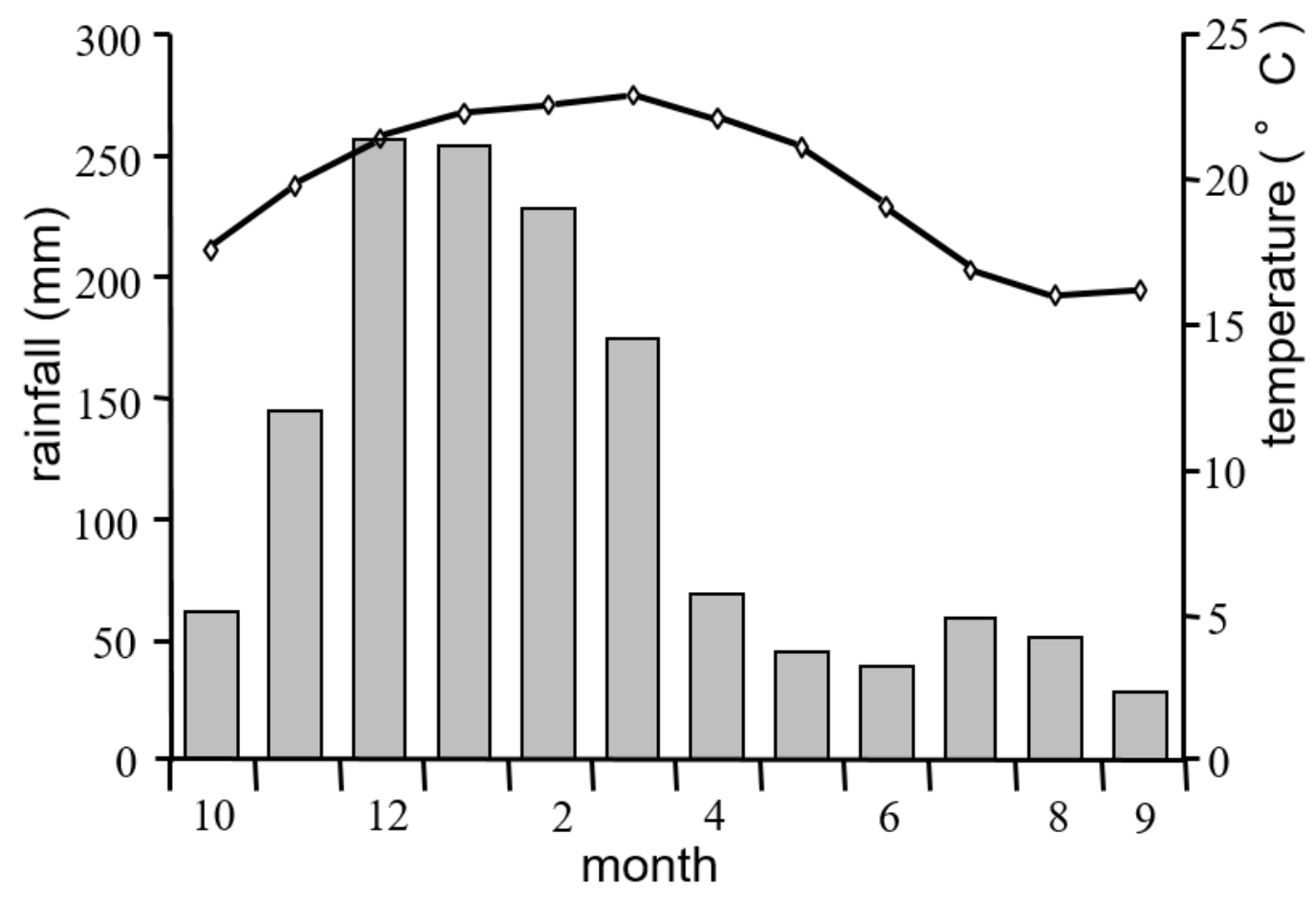

Figure 1. Average monthly variations in the temperature (solid line) and the rainfall (bar diagram). The records had been performed by the meteorological station of Moramanga, over 20 years (19711990). The village of Saharevo is $15 \mathrm{~km}$ directly north-west of Moramanga.

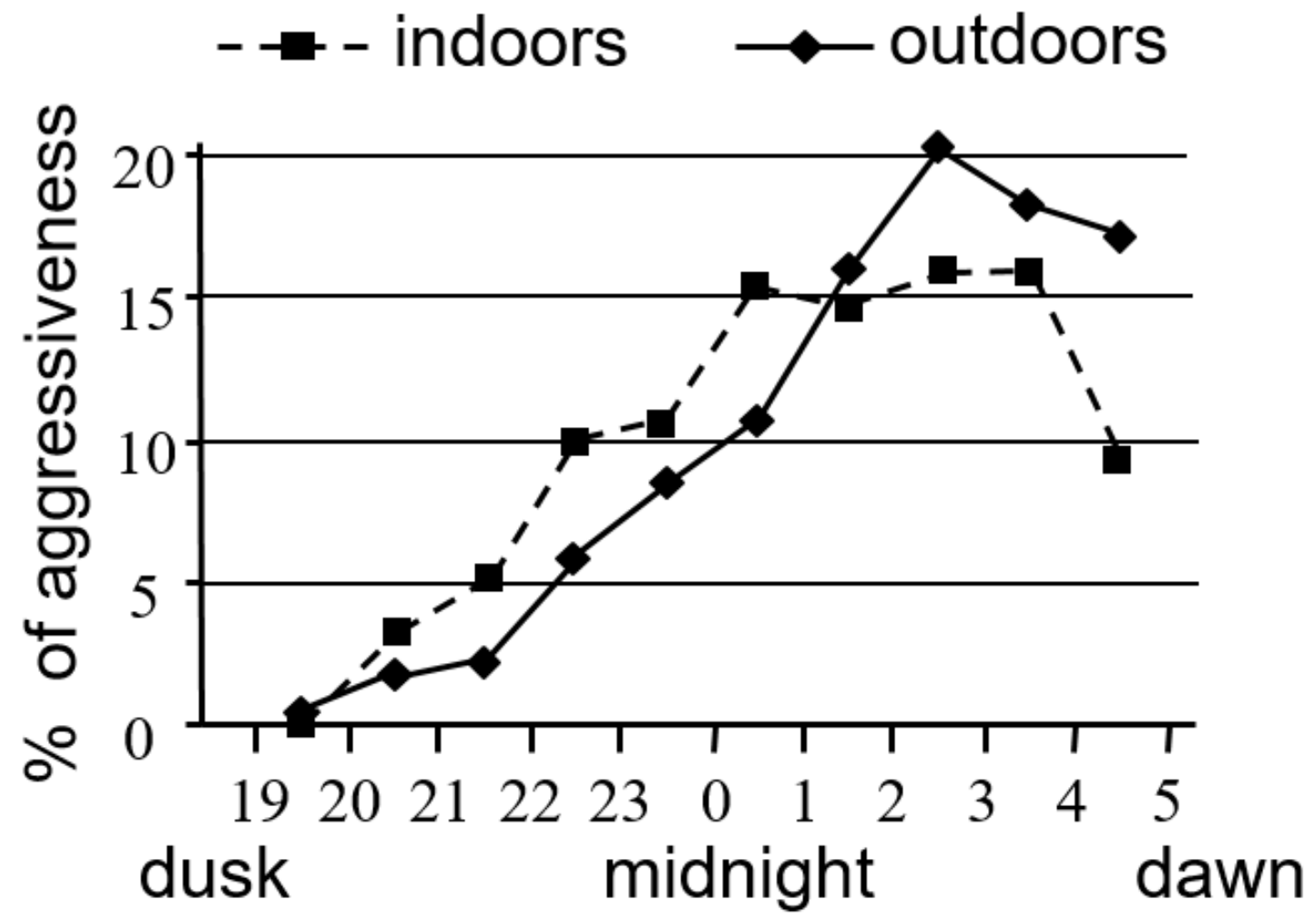

Figure 2. Hourly variations in the densities of the main malaria vector Anopheles funestus (total 140 and 295 mosquitoes indoor and outdoor, respectively) presented in percentages of total aggressiveness in all night human landing catches indoors (dashed line) and outdoors (solid line). 
Table 1. Mosquito collections according to methods of catches, in the village of Saharevo, Madagascar.

\begin{tabular}{|c|c|c|c|c|c|c|}
\hline \multirow[t]{2}{*}{ Methods of catches } & \multicolumn{2}{|c|}{ human landing } & \multicolumn{2}{|r|}{ resting } & \multirow[t]{2}{*}{ Total } & \multirow[t]{2}{*}{$\%$} \\
\hline & indoor & outdoor & indoor pyrethrum spray & outdoor Muirhead-Thomson pits & & \\
\hline Whole catching effort & 336 man-nights & 336 man-nights & 140 bedroom-nights & 176 pit-nights & & \\
\hline Anopheles funestus & 140 & 295 & 245 & 48 & 728 & 11.8 \\
\hline An. arabiensis & 13 & 70 & 2 & 41 & 126 & 2.0 \\
\hline An. gambiae & 27 & 150 & 5 & 8 & 190 & 3.1 \\
\hline An. mascarensis & 62 & 437 & 5 & 302 & 806 & 13.0 \\
\hline An. coustani & 59 & 754 & 0 & 0 & 813 & 13.1 \\
\hline An. squamosus-cydippis & 131 & 924 & 0 & 0 & 1,055 & 17.0 \\
\hline An. rufipes & 4 & 0 & 0 & 0 & 4 & 0.1 \\
\hline An. maculipalpis & 13 & 23 & 0 & 0 & 36 & 0.6 \\
\hline An. pharoensis & 0 & 4 & 0 & 0 & 4 & 0.1 \\
\hline An. pauliani & 95 & 0 & 0 & 0 & 95 & 1.5 \\
\hline An. brunnipes & 7 & 11 & 0 & 0 & 18 & 0.3 \\
\hline Culex antennatus & 21 & 241 & 0 & 0 & 262 & 4.2 \\
\hline Cx. univittatus/neavei & 104 & 811 & 0 & 0 & 915 & 14.8 \\
\hline Cx. quinquefasciatus & 39 & 510 & 12 & 5 & 566 & 9.1 \\
\hline Cx. decens & 17 & 206 & 1 & 0 & 224 & 3.6 \\
\hline Cx. bitaeniorhynchus & 0 & 4 & 0 & 0 & 4 & 0.1 \\
\hline Cx. tritaeniorhynchus & 0 & 8 & 0 & 0 & 8 & 0.1 \\
\hline Cx. sitiens & 0 & 0 & 0 & 0 & 0 & 0.0 \\
\hline$C x$. giganteus & 12 & 191 & 2 & 1 & 206 & 3.3 \\
\hline Cx. poicilipes & 1 & 6 & 0 & 0 & 7 & 0.1 \\
\hline Aedes albopictus & 0 & 5 & 0 & 0 & 5 & 0.1 \\
\hline Ae. tiptoni & 0 & 9 & 0 & 0 & 9 & 0.1 \\
\hline Ae. aegypti & 0 & 3 & 0 & 0 & 3 & 0.0 \\
\hline Ae. fowleri & 1 & 1 & 0 & 0 & 2 & 0.0 \\
\hline Ae. vittatus & 0 & 1 & 0 & 0 & 1 & 0.0 \\
\hline Ae. circumluteolus & 4 & 16 & 0 & 0 & 20 & 0.3 \\
\hline Mansonia uniformis & 6 & 74 & 0 & 0 & 80 & 1.3 \\
\hline Coquillettidia grandidieri & 0 & 5 & 0 & 0 & 5 & 0.1 \\
\hline Total & 756 & 4,759 & 269 & 405 & 6,192 & 100.0 \\
\hline
\end{tabular}


Table 2. Monthly variations in the densities of anopheline mosquitoes, potential vectors of malaria in the village of Saharevo, Madagascar, from October 2003 to September 2004 (total 1,850 for the four mosquito species) per human indoor with all night human landing catches with indoor human subjects (man indoor), per human outdoor with all night human landing catches with outdoor human subjects (man outdoor), per room with pyrethrum spray catches in bedrooms examined during the morning (room), and per pit with Muirhead-Thomson' pit shelters examined early after sunrise (pit).

\begin{tabular}{|c|c|c|c|c|c|c|c|c|c|c|c|c|c|c|c|}
\hline & & Oct & Nov & Dec & Jan & Feb & Mar & Avr & May & Jun & Jul & Aug & Sep & Arithmetic mean & Geometric mean \\
\hline An. funestus & room & 0 & 0.167 & 0.263 & 0.188 & 0.833 & 4.467 & 8.583 & 3.750 & 0.667 & 0 & 0 & 0 & 1.576 & 0.821 \\
\hline \multirow[t]{4}{*}{ An. gambiae } & man indoor & 0 & 0.094 & 0.062 & 0.031 & 0.375 & 0.156 & 0.093 & 0.031 & 0 & 0 & 0 & 0 & 0.070 & 0.066 \\
\hline & man outdoor & 0 & 0.094 & 0.406 & 0.281 & 1.000 & 1.875 & 0.719 & 0.281 & 0.025 & 0 & 0 & 0 & 0.390 & 0.310 \\
\hline & room & 0 & 0 & 0.053 & 0 & 0 & 0 & 0.250 & 0.083 & 0 & 0 & 0 & 0 & 0.032 & 0.030 \\
\hline & pit & 0.125 & 0 & 0 & 0.125 & 0 & 0.250 & 0 & 0 & 0 & 0 & 0 & 0 & 0.042 & 0.039 \\
\hline \multirow{3}{*}{ An. arabiensis } & man outdoor & 0.000 & 0.031 & 0.156 & 0.281 & 0.531 & 0.938 & 0.094 & 0.125 & 0 & 0 & 0 & 0.063 & 0.185 & 0.160 \\
\hline & room & 0 & 0 & 0.105 & 0 & 0 & 0 & 0 & 0 & 0 & 0 & 0 & 0 & 0.009 & 0.008 \\
\hline & pit & 0 & 0.063 & 0.350 & 0.813 & 0.438 & 0.500 & 0 & 0.125 & 0.050 & 0 & 0 & 0 & 0.195 & 0.171 \\
\hline \multirow[t]{4}{*}{ An. mascarensis } & man indoor & 0.062 & 0.062 & 0 & 0.031 & 0.218 & 0.187 & 0.656 & 0.250 & 0.300 & 0.062 & 0.083 & 0.062 & 0.165 & 0.153 \\
\hline & man outdoor & 0.125 & 0.688 & 0.250 & 0.375 & 0.313 & 1.188 & 3.438 & 2.094 & 2.100 & 1.250 & 2.375 & 0.438 & 1.219 & 1.010 \\
\hline & room & 0.167 & 0.083 & 0.053 & 0 & 0 & 0 & 0.083 & 0 & 0.067 & 0 & 0 & 0 & 0.038 & 0.037 \\
\hline & pit & 5.000 & 2.250 & 0.400 & 0.250 & 0.500 & 1.350 & 2.313 & 3.688 & 1.300 & 1.250 & 1.917 & 3.000 & 1.935 & 1.637 \\
\hline
\end{tabular}


Table 3. Entomological parameters for anopheline potential vectors of malaria in the village of Saharevo, Madagascar.

\begin{tabular}{|c|c|c|c|c|c|c|c|c|c|c|}
\hline & Endophagy & $\begin{array}{l}\text { Anthropophily } \\
\text { bedroom } \\
\text { resting }\end{array}$ & $\begin{array}{l}\text { Anthropophily } \\
\text { pit resting }\end{array}$ & $\begin{array}{l}\text { \% positive } \\
\text { bovid } \\
\text { (zebus) } \\
\text { bedroom } \\
\text { resting }\end{array}$ & $\begin{array}{l}\% \text { positive } \\
\text { bovid } \\
\text { (zebus) pit } \\
\text { resting }\end{array}$ & $\begin{array}{l}\text { \% positive } \\
\text { CSP-ELISA } \\
\text { P. falciparum }\end{array}$ & $\begin{array}{l}\% \\
\text { positive } \\
\text { CSP - } \\
\text { ELISA } \\
P . \text { vivax }\end{array}$ & $\begin{array}{l}\text { \% positive } \\
\text { CSP - } \\
\text { ELISA } \\
\text { P. malariae }\end{array}$ & $\begin{array}{l}\text { \% positive } \\
\text { CSP -ELISA } \\
\text { Plasmodium } \\
s p .\end{array}$ & $\begin{array}{l}\text { Annual } \\
\text { entomological } \\
\text { inoculation rate } \\
\text { indoor }\end{array}$ \\
\hline An. funestus & $\begin{array}{c}32.2 \% \\
(140 / 435)\end{array}$ & $\begin{array}{c}90 \% \\
(109 / 121)\end{array}$ & $\begin{array}{l}21 \% \\
(4 / 19)\end{array}$ & $\begin{array}{c}13 \% \\
(16 / 121)\end{array}$ & $\begin{array}{c}74 \% \\
(14 / 19)\end{array}$ & $\begin{array}{l}1.42 \% \\
(9 / 633)\end{array}$ & $\begin{array}{l}0.31 \% \\
(2 / 633)\end{array}$ & $\begin{array}{c}0 \% \\
(0 / 633)\end{array}$ & $\begin{array}{c}1.58 \% \\
(10 / 633)\end{array}$ & 2.15 \\
\hline lbiae s.l. & $\begin{array}{c}15.4 \% \\
(40 / 260)\end{array}$ & $\begin{array}{l}100 \% \\
(4 / 4)\end{array}$ & $\begin{array}{c}0 \% \\
(0 / 24)\end{array}$ & $\begin{array}{l}0 \% \\
(0 / 4)\end{array}$ & $\begin{array}{c}100 \% \\
(24 / 24)\end{array}$ & $\begin{array}{l}0.47 \% \\
(1 / 211)\end{array}$ & $\begin{array}{c}0 \% \\
(0 / 211)\end{array}$ & $\begin{array}{c}0 \% \\
(0 / 211)\end{array}$ & $\begin{array}{l}0.47 \% \\
(1 / 211)\end{array}$ & 0.18 \\
\hline An. mascarensis & $\begin{array}{c}12.4 \% \\
(62 / 499)\end{array}$ & $\begin{array}{l}0 \% \\
(0 / 2)\end{array}$ & $\begin{array}{l}0 \% \% \\
(0 / 127)\end{array}$ & $\begin{array}{l}100 \% \\
(0 / 2)\end{array}$ & $\begin{array}{c}97 \% \\
(123 / 127)\end{array}$ & $\begin{array}{l}0.37 \% \\
(1 / 268)\end{array}$ & $\begin{array}{c}0 \% \\
(0 / 268)\end{array}$ & $\begin{array}{c}0.37 \\
(1 / 268)\end{array}$ & $\begin{array}{l}0.75 \% \\
(2 / 268)\end{array}$ & 0.45 \\
\hline
\end{tabular}

